\title{
Effect of Exercise Activity and Food Consumption Behavior on the Success of Smoking Cessation Program
}

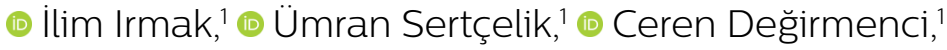

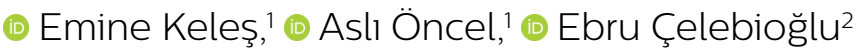

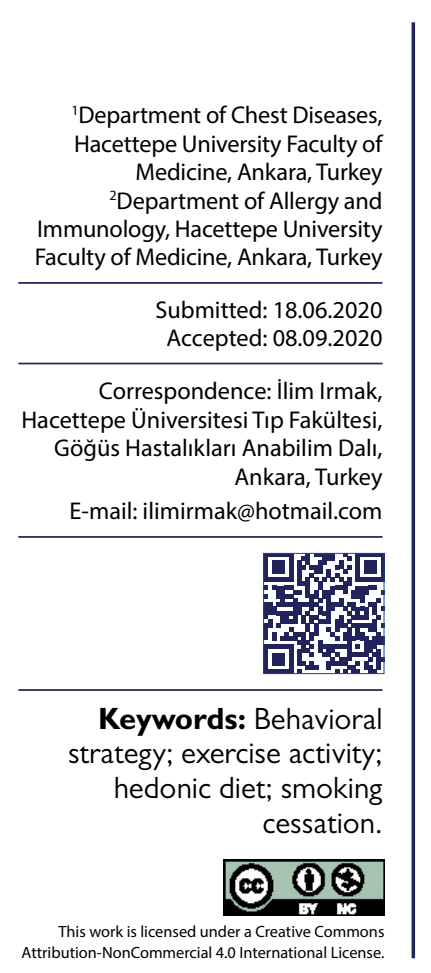

\begin{abstract}
Objective: Food and beverage preferences and exercise activities suppress the desire to smoke and extend the cessation period. The aim of the present study was to investigate effects of food consumption and physical activities on the success of a smoking cessation program.
\end{abstract}

Methods: In our retrospective cohort study, demographics, smoking cessation therapy features, levels of addiction, treatment results, food preferred in case of desire to smoke during follow-up, and physical activities of 119 patients monitored within the scope of smoking cessation program in our site were recorded. The data of the groups with successful and unsuccessful smoking cessation were analyzed by comparison.

Results: The successful group had more patients who quit smoking within the first one month in the treatment process and gained weight than the unsuccessful group $(p<0.00 \mathrm{I}$ and $\mathrm{p}<0.00 \mathrm{I}$, respectively). Compared to the successful group, the unsuccessful group recorded a higher level of addiction and relapse $(p=0.04, p=0.00 \mathrm{I}$, respectively). The use of varenicline and nicotine gum among pharmacological treatments did not differ between groups, nicotine patch was more frequently used higher in the unsuccessful group $(p=0.046)$. The successful group also had more patients who consumed hedonic diet among the behavioral strategies in case of urge to smoke $(p=0.04)$.

Conclusion: The preference for hedonic foods in case of urge to smoke in patients who underwent smoking cessation treatment and implementing multiple strategies are associated with the success of the treatment, unlike exercise activity. This study may provide preliminary support for an eating strategy using a dietary plan and multi-strategy for the success of smoking cessation programs.

\section{INTRODUCTION}

Smoking is a treatable public health issue that leads to many diseases and most deaths in the world. In a smoking cessation program, the treatment of addiction with neurobiological pathogenesis involves nicotine replacement and nicotine-free pharmacological approaches, with proven efficiency. ${ }^{[1]}$ Considering the psychological and behavioral pathogenesis, behavioral and cognitive approaches by providing psychosocial support bringing in motivation and coping skills in cessation of smoking increases the likelihood of treatment success. ${ }^{[2]}$ In addition, the most significant indicators of success are the ability to cope with the urge to smoke and thus the length of the non-smoking period. However, people have different coping behaviors. In order to cope with the intense urge to smoke during the smoking cessation period, cognitive and behavioral strate- gies may be implemented as they help minimize the severe instant urges and extend the cigarette-free period. ${ }^{[3]}$

Activities and food intake are among the behavioral strategies used during smoking cessation. Previous studies indicated that exercise increases the neural activation in the area of the brain associated with dopamine reward system in a way similar with smoking and that substituting cigarette with exercise minimizes the urge to smoke and abstinence symptoms. ${ }^{[4-6]}$ The hedonic eating habit triggers food consumption, and an increased sensitivity of the reward system to food may contribute to the pathophysiology of obesity. ${ }^{[7]}$ Functional neuroimaging studies reveal that brain changes associated with hedonic eating, e.g., enhanced mesolimbic dopamine activity, are also seen in addiction, which is characterized by compulsive reward-seeking behavior. ${ }^{[8]}$ This is particularly associated 
with such as high-hedonic diet consumptions calorie, fatty and tasty foods, and weight gain. ${ }^{[9]}$ The change of eating and drinking habit in those who quit smoking and the tendency to eat to substitute smoking in case of urge to smoke explains the weight gain.

Actionable behaviors include exercises such as walking or sports, while non-exercise activities are watching television and using social media. Eating/drinking habits include consumption of raw neutral foods such as water, fruit or vegetable consumption or practice of a hedonic diet with processed and sweetened tasty foods that exhilarates while eating such as snacks, chocolates, coffee. Very little is known about the outcomes of the smoking cessation treatment based on the actionable activities (exercise preferences) and food choices (hedonic foods) preferred in case of an urge to smoke. In the present study, we aimed to evaluate the activities performed to cope with severe urge to smoke in terms of hedonic food consumption and exercise and examine their effects on the treatment success in patients under smoking cessation program.

\section{MATERIALS AND METHODS}

This single-center retrospective cohort study was conducted in the Smoking Cessation Clinic of the University School of Medicine from October 23, 2018 to November 이, 2019.

\section{Participants}

We included all adult patients over 18 years of age who were addicted to smoking participating in a smoking cessation program of our center within the study period. $\mathrm{Pa}$ tients who did not complete the smoking cessation program and those who had less than six months of follow-up after completing the smoking cessation program were excluded from the study.

\section{Procedure}

Every patient who applied to the smoking cessation clinic of our center and included in the smoking cessation program was registered in the Tobacco Addiction Treatment Monitoring System (TUBATIS) https://hsgm.saglik.gov.tr/ tr/tubatis.html database organized by our country's Ministry of Health Directorate of Public Health. This is a current database used in smoking cessation clinics, in which the patient data is registered and accessed by a password specific to the authorized physician who examines the patient. Our smoking cessation clinic is run by two pulmonary disease specialists using this database. In our center, routine face-to-face meetings are conducted with each patient accepted to the smoking cessation program for at least 30 minutes for the first application and for at least 15 minutes for control visits, and psychosocial support is provided through cognitive and behavioral treatment methods including motivational and preventive approaches to quit smoking. ${ }^{[10-12]}$ In addition, customized pharmacological treatments including varenicline and/or nicotine replace- ment (gum and/or patch) based on the evaluation of the threating physician are provided to minimize physical abstinence and cessation process. Each patient in smoking cessation program is followed up at the first control on the first week of their initial application and at the second control within the first one month. The subsequent follow-up visits become monthly control visits and may be more frequent when necessary based on the physician's evaluation. This program lasts at least 3 months for those who fail to quit smoking during the treatment period, and it may last shorter for those who quit smoking earlier depending on their status of cessation.

\section{Definitions}

All patients admitted to smoking cessation clinic and included in to the smoking cessation program were considered as individuals receiving smoking cessation treatment as of the application date. The date of quit smoking were accepted as the date they attempt to give up smoking.

Smoking at least one cigarette without continuation after quit date was defined as a lapse, and continuous smoking as a relapse. At least 6 months without smoking was defined as successful.

The nicotine dependence levels of the patients were determined by Fagerström Test for Nicotine Dependence, which consists of questions related to the typical smoking pattern, which classifies nicotine dependence into mild ( $1-3$ point), moderate (4-7 point), high (8-10 point) dependency according to score. ${ }^{[13]}$ Hedonic diet was defined as the consumption of high-calorie food with high fat, sugar or salt, which is processed to make it tastier (for example: sugar gum, coffee, nuts, chocolate, snacks, etc.). On the other hand, the neutral food such as fruit, raw vegetables, soda, sugar-free gum or the food that do not contain high-calorie, high sugar, or salt, which are not processed were defined as non-hedonic diet.

Exercise activity was defined as activities that require active actions such as sports, exercise, and walking. On the other hand, passive activities that do not require exercise and physical action were considered as non-exercise activity (e.g., chatting, social media use, television, music).

\section{Data}

The demographical data of the patients such as age, sex, occupation, marital status and having children, comorbidities, cigarette pack/year, treatment start and end dates, pharmacological and non-pharmacological treatment (varenicline, nicotine replacement therapy, and psychosocial support), current smoking and non-smoking status, presence of lapse or relapse, and Fagerström nicotine dependency scores were obtained from TUBATIS database. The information regarding the behavioral and drinking habits of the patients in case of an intense urge to smoke and regarding their weight gain was obtained from the control visit records. Patients' ID information was protected strictly. 


\section{Statistical Analyses}

The data were collected from the files of the patients, obtained the operating systems of the hospital and analyzed using IBM SPSS Statistics for Windows v.23.0. ${ }^{[14]}$ The normality of variables was examined with Shapiro-Wilk test, boxplots, and Q-Q plots. Descriptive statistics are shown as mean and standard deviation for normally distributed variables, while the median and $25^{\text {th }}$ and $75^{\text {th }}$ percentiles for normality assumption were not satisfied. Furthermore, for continuous variables independent two groups were compared with independent samples t-test or Mann-Whitney $U$ tests based on normality assumption for continuous variables. On the other hand, categorical variables were compared with Chi-Square test. The level of statistical significance was set at $p$-value $<0.05$. All reported $\mathrm{p}$-values are two-sided.

\section{RESULTS}

A total of 119 patients were admitted throughout the study, there were 45 female and 74 male $(37.8 \%$ and $62.2 \%$ respectively) with a mean age of $41.2 \pm 12$ years and median age was 39 with the range of 19 and 77 years. The number of patients with a successful treatment were $52(43.7 \%)$ and with an unsuccessful treatment were 67 (56.3\%) (Fig. I).
Demographics of patients are shown in Table I. Of the patients 82 (68.9\%) were married and 83 (69.7\%) were parenting. The number of patients who defined their job as stressful was 62 (52.1\%). The education level of the majority of the patients was high-school and university (each of them $n=38,31.9 \%)$. The average cigarette pack/year was $27.1 \pm 15.9$. Of the patients 5 (4.2\%) were smoking hookah, $8(6.7 \%)$ was smoking electronic cigarette. The number of patients with comorbidities was 49 (4I.2\%) and the most common comorbidities were hypertension $(n=\mid 4,11.8 \%)$ and depression $(n=11,9.2 \%)$. Of the patients with depression 5 were taking antidepressants drugs that belonged to serotonin reuptake inhibitor group. The mean dependency score of the study group was $6.9 \pm 2$. I4. The number of the patients with high dependency was 49 (4l.2\%) while the number of patients with moderate and mild dependencies was 70 (58.8\%). The number of patients taking varenicline as pharmacological treatment was 106, the number of those using nicotine patch was 12 , and nicotine gum was $5(89.1 \%, 10.1 \%$ and $4.2 \%$ respectively). The number of patients receiving combination treatment with varenicline and nicotine gum was 2 ( $1.6 \%$ ), those receiving combination treatment with varenicline and nicotine patch were 2 (I.6\%), and there was only I person using nicotine patch and gum together $(0.8 \%)$. When the behavioral strategies preferred in case of severe urge to smoke during the treat-

Patients admitted to Smoking Cessation Outpatient Clinic ( $\mathrm{n}=181)$

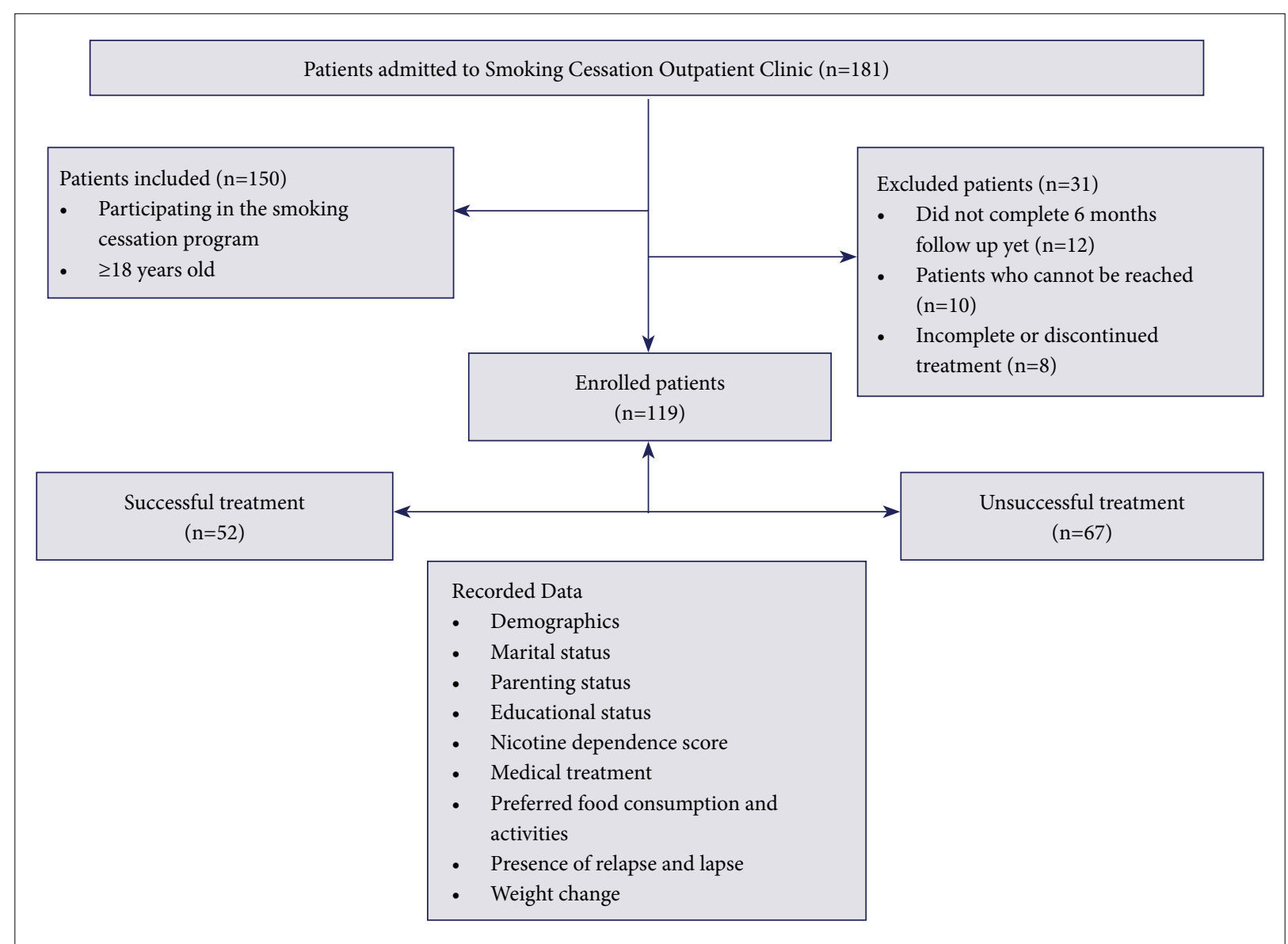

Figure 1. Flow chart of the study. 
Table I. Characteristics of the patients

\begin{tabular}{|c|c|}
\hline & $\begin{array}{l}\text { All patients } \\
(n=119)\end{array}$ \\
\hline \multicolumn{2}{|l|}{ Gender, n (\%) } \\
\hline Female & $45(37.8)$ \\
\hline Age, median (min-max) & $39(19-77)$ \\
\hline Married, n (\%) & $82(68.9)$ \\
\hline Parenting, n (\%) & $83(69.7)$ \\
\hline \multicolumn{2}{|l|}{ Educational status, n (\%) } \\
\hline Literate & $\mathrm{I}(0.8)$ \\
\hline Primary school & $20(16.8)$ \\
\hline Middle school & $22(18.5)$ \\
\hline High school & $38(31.9)$ \\
\hline University & $38(31.9)$ \\
\hline Stressful job, n (\%) & $62(52.1)$ \\
\hline Alcohol, n (\%) & $33(27.7)$ \\
\hline Smoking $\mathrm{p} / \mathrm{y}$, median (min-max) & $25(2-80)$ \\
\hline Hookah, n (\%) & $5(4.2)$ \\
\hline Electronic cigarette, n (\%) & $8(6.7)$ \\
\hline Comorbidities, n (\%) & $49(4 \mid .2)$ \\
\hline Hypertension & $14(1 \mid .8)$ \\
\hline Depression & II (9.2) \\
\hline Asthma & $7(5.9)$ \\
\hline Diabetes mellitus & $7(5.9)$ \\
\hline Heart failure & $6(5)$ \\
\hline GERD & $6(5)$ \\
\hline Antidepressant drug use, n (\%) & $5(4)$ \\
\hline $\begin{array}{l}\text { Fagerström Nicotine Dependence } \\
\text { score, mean } \pm S D\end{array}$ & $6.9 \pm 2.14$ \\
\hline \multicolumn{2}{|l|}{ Addiction level, $n(\%)$} \\
\hline High addiction & $49(4 \mid .2)$ \\
\hline Moderate addiction & $67(56.3)$ \\
\hline Low addiction & $3(2.5)$ \\
\hline \multicolumn{2}{|l|}{ Pharmacological treatment, $\mathrm{n}(\%)$} \\
\hline Varenicline & $106(89.1)$ \\
\hline Nicotine gum & $5(4.2)$ \\
\hline Nicotine patch & $12(10.1)$ \\
\hline \multicolumn{2}{|l|}{ Behavioral strategies, n (\%) } \\
\hline Hedonic diet & $68(57.1)$ \\
\hline Non-hedonic diet & $43(36.1)$ \\
\hline Non-exercise activity & $44(37)$ \\
\hline Exercise activity & $45(37.8)$ \\
\hline Number of strategies, mean $\pm S D$ & $1.6 \pm 1.07$ \\
\hline Weight gain, n (\%) & $64(53.8)$ \\
\hline Treatment success, $\mathrm{n}(\%)$ & $52(43.7)$ \\
\hline
\end{tabular}

SD: Standard deviation; COPD: Chronic obstructive pulmonary disease; GERD: Gastroesophageal reflux disease; $p / y$ : Pack/year.

ment process were reviewed, those with hedonic diet intake were 68 (57.1\%), those with non-hedonic diet intake were $43(36.1 \%)$, those who preferred exercise activity were $45(37.8 \%)$, and those who preferred non-exercise activity were 44 (37\%) patients (Fig. 2). The number of average strategies applied among these preferences was

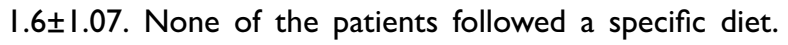

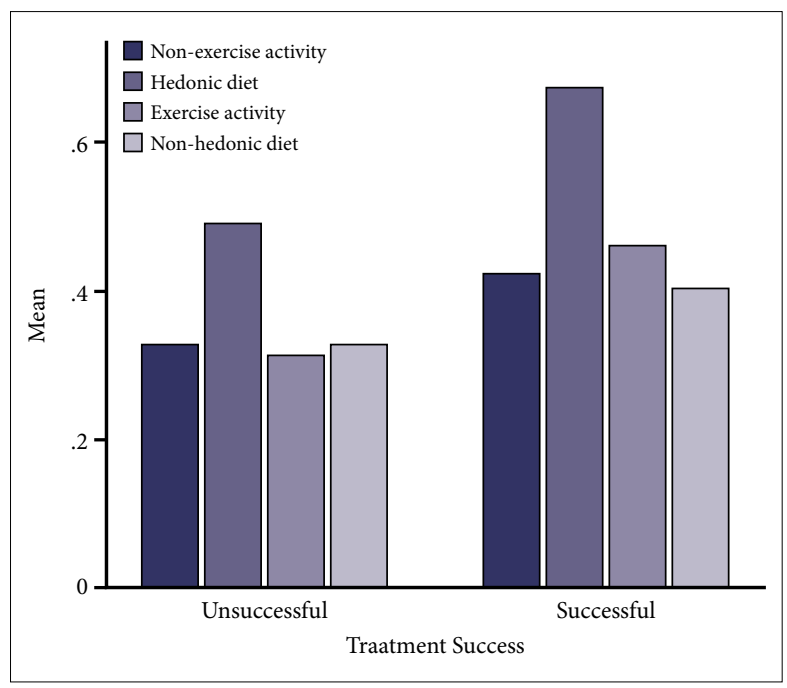

Figure 2. Distribution of behavioral strategies according to treatment success.

The number of the patients who gained weight after treatment was 64 (53.8\%).

The comparison of the groups with a successful treatment and an unsuccessful treatment are given in Table 2. In both groups, the demographics of the patients such as age, gender, marital status, children, and education status were similar. The clinical properties such as cigarette pack/year, presence of comorbidity, antidepressant drug use, and dependency scores differed between the groups. Those who quit smoking within the first month of treatment process and those who gained weight were more in the successful group ( $p<0.001$ and $p<0.001$, respectively). The number of patients with higher dependency was high in the group with unsuccessful treatment $(p=0.04)$. While the presence of lapse during the treatment process was similar in both groups $(p=0.07)$, there were no relapses in the successful group, however it was significantly higher in the unsuccessful group $(p=0.00 \mathrm{I})$. The use of varenicline and nicotine gum as pharmacological treatment options provided to the patients did not differ between groups. However, the use of nicotine patch was higher in the group where the treatment failed $(p=0.046)$. Those who preferred hedonic diet among the behavioral strategies applied in case of intense urge to smoke were significantly more in the group where the treatment was successful $(p=0.04)$. Additionally, the number of strategies implemented in the successful group was higher than in the unsuccessful group $(p=0.0 \mathrm{l})$.

\section{DISCUSSION}

The primary findings of this study were that preferring hedonic food in case of severe urge to smoke in people undergoing smoking cessation program was associated with the treatment success. Besides, the weight gain was higher in individuals who had a successful treatment and who preferred hedonic diet. These primary findings of the study confirm the hypothesis that those who quit smoking substitute nicotine, which has an effect activating the 
Table 2. Comparison of characteristics of study groups

\begin{tabular}{|c|c|c|c|}
\hline & $\begin{array}{l}\text { Successful treatment } \\
\qquad(n=52)\end{array}$ & $\begin{array}{l}\text { Unsuccessful treatment } \\
\qquad(n=67)\end{array}$ & P-value \\
\hline Female, n (\%) & $19(36.5)$ & $26(38.8)$ & 0.8 \\
\hline Age, mean $\pm S D$ & $43 \pm 11.4$ & $39.8 \pm 12.3$ & 0.15 \\
\hline Married, n (\%) & $37(7 \mathrm{I} .1)$ & $45(67.1)$ & 0.64 \\
\hline Parenting, n (\%) & $39(75)$ & $44(65.6)$ & 0.27 \\
\hline \multicolumn{4}{|l|}{ Educational status, n (\%) } \\
\hline Primary school & $5 \quad(9.8)$ & $15(22.4)$ & 0.321 \\
\hline Middle school & $10(19.6)$ & $12(17.9)$ & \\
\hline High school & $17(33.3)$ & $21(31.3)$ & \\
\hline University & $19(37.3)$ & $19(28.4)$ & \\
\hline Stressful job, n (\%) & 29 & 33 & 0.48 \\
\hline Alcohol consumption, n (\%) & $20(38.4)$ & $13(19.4)$ & 0.02 \\
\hline Smoking p/y, median (QI-Q3) & $27.5(20-40)$ & $20(12-35)$ & 0.043 \\
\hline Presence of a comorbidity, n (\%) & $25(48)$ & $24(35.8)$ & 0.17 \\
\hline Antidepressant drug use, n (\%) & $6(11.5)$ & $2(2.9)$ & 0.06 \\
\hline Fagerström nicotine dependence score, median (QI-Q3) & $6(5-8)$ & $7(6-9)$ & 0.185 \\
\hline High addiction, $n(\%)$ & $16(30.7)$ & $33(49.2)$ & 0.04 \\
\hline Weight gain, n (\%) & $38(73)$ & $26(38.8)$ & $<0.001$ \\
\hline Lapse under treatment, $\mathrm{n}(\%)$ & $3(5.7)$ & $6(8.9)$ & 0.07 \\
\hline Relapse under treatment, $\mathrm{n}(\%)$ & 0 & $7(10.4)$ & 0.001 \\
\hline Quit smoking in the first month of treatment, $\mathrm{n}(\%)$ & $50(96.1)$ & $24(35.8)$ & $<0.001$ \\
\hline \multicolumn{4}{|l|}{ Pharmacological treatment, n (\%) } \\
\hline Varenicline & $49(94.2)$ & $57(85)$ & 0.11 \\
\hline Nicotine gum & I (I.9) & $4(5.9)$ & 0.385 \\
\hline Nicotine patch & $2(3.8)$ & $10(14.9)$ & 0.046 \\
\hline \multicolumn{4}{|l|}{ Behavioral strategies, n (\%) } \\
\hline Hedonic diet & $35(67.3)$ & $33(49.2)$ & 0.04 \\
\hline Non-hedonic diet & $21(40.3)$ & $22(32.8)$ & 0.39 \\
\hline Non-exercise activity & $22(42.3)$ & $22(32.8)$ & 0.28 \\
\hline Exercise activity & $24(46.1)$ & $21(31.3)$ & 0.09 \\
\hline Number of strategy, mean $\pm S D$ & $1.9 \pm 1$ & $1.4 \pm 1$ & 0.01 \\
\hline
\end{tabular}

reward mechanism of the brain with a rewarding food and thus, they have a tendency to hedonic diet.

Food intake is a behavioral activity affected by demand and enjoyment urges mediated by dopaminergic and opioid pathways. ${ }^{[15]}$ The eating behavior beyond metabolic needs may also be explained through these mechanisms. In previous studies, this view is supported by showing that this hedonic response was inhibited with opioid antagonist in animals consuming tastier food in order to preserve their body weight. Likewise, the decrease in the dopamine reward activation in individuals who quit smoking and to stimulate the dopamine reward pathway lead to the substitution of cigarette with food. ${ }^{[16]}$ In support of this, it was shown that cessation of smoking is related to an increase calorie intake in the form of hedonic food consumption particularly such as tasty snacks with high fat and that $80-90 \%$ of the population who quit smoking gained weight due to this. ${ }^{[17,18]}$ The eating-drinking habit has even become a behavioral strategy, which a person who quit smoking may implement to cope with nicotine abstinence and intense urge to smoke. However, the effect of hedonic diet on the treatment success of smoking cessation is not clearly known.

Primary findings in this study provide preliminary support for the use of new proper coping eating strategy with dietary restraint and palatable but healthy (specific dietary) for the treatment success in the smoking cessation programs.

In our study, since all patients were included in a smoking cessation program consisting of psychological support and proper pharmacological treatment with an impact on treatment success, the patients were almost under equal conditions in terms of the other factors that may affect the treatment success except for the strategies we studied. One of the pharmacological treatments given to quit smoking is bupropion treatment, which acts through the inhibition of dopamine reuptake. The food rewards mechanism by acting on the dopamine reward pathways is an 
agent, which may affect the weight and eating habit. ${ }^{[19]}$ In our study, none of the patients received bupropion treatment, and so, this excludes any medication that would affect the results. When both conditions are considered, this empowers the accuracy of the primary result we obtained.

Another strategy used in case of an urge to smoke is exercise activities. In our study, there are different results regarding the impact of exercise on coping with abstinence. While it was mentioned that exercise increases the dopamine reward activation and ensures coping with abstinence and intense urge to smoke by substituting with cigarette like in eating habit, on the other hand, it was indicated that exercise provides this effect for a short time or that it further increases abstinence. ${ }^{[4,5]}$ In a meta-analysis where twenty studies were extensively reviewed, only two studies mentioned that exercise helped quitting smoking and in four studies, it was determined that those who exercise had higher abstinence. There are studies reporting higher treatment success by combining smoking cessation program with exercise. ${ }^{[20]}$ In our study, we determined that exercise was not associated with treatment success, however, exercise was more preferred in the successful group compared to the unsuccessful group. Although our findings support the studies, which determined that exercise was not helpful in quitting smoking, it may be insufficient in validating the result we obtained as the type, intensity, and length of the exercises were not standardized.

Individuals may also present passive behaviors with cognitive content, which are not qualified as exercise such as chatting, social media use, deep breathing, reading, and focus on thoughts other than smoking. In a study where behavioral strategy types were analyzed, it was concluded that any strategy may decrease the urge levels and prolong the lapse cycles, however it did not contribute to the tolerability of an individual in coping. But the study found that these types of strategy have no superiority over another, yet they were more advantageous compared to using no strategies. Besides, use of multiple strategies was reported to be effective in coping with high urge. ${ }^{[3]}$ In our study, non-exercise activity was found to be not associated with smoking cessation treatment success, but the use of multiple strategies were found to be associated with treatment success as in previous studies. This result we obtained indicate that exercise and non-exercise behaviors have positive effect on the treatment success when both behaviors are considered in terms of coping with urge to smoke in the attempt to quit smoking. Our study is the first research, which reviews the impact of hedonic or non-hedonic food intake and exercise or non-exercise activities under the smoking cessation program on "smoking cessation treatment success."

It is important to determine the factors that affect quit rates in order to build an efficient treatment program. In our study, gender, marital status, being a parent, education level, stressful occupation, comorbidity, nicotine dependency level, and pharmacological treatment types were not associated with the treatment success. Pack-year, alcohol consumption, and being able to quit smoking on the first month of the treatment were associated with the treatment success. On the other hand, high dependency, use of nicotine patch and gum during treatment was found to be associated with treatment failure. Although there are researches supporting that there is no difference in quitting smoking in terms of gender as in our study, there are counter results reported. ${ }^{[21,22]}$ In comprehensive researches conducted, starting to smoke at an early age, high pack/year, high dependency, nicotine replacement therapy, psychiatric disease, and taking psychiatric medication were observed to decrease the success. On the other hand, in the same studies, a higher education level, being married, having quit alcohol, and presence of comorbidity increased the success rates. ${ }^{[21,23]}$ Although some of the results we obtained validate this information, ethnical differences, and socioeconomic conditions were also indicated as factors influencing the treatment success, which may be due to the sociocultural factors in our study such as the education level, marital status, and being parents that did not lead to any differences on the treatment results.

Despite alcohol consumption is known to trigger smoking, the relevance of alcohol consumption with the treatment success in our study supports the hypothesis made and validated by Zimmerman et al. ${ }^{[24]}$ indicating that "individuals who like consuming cigarette and alcohol together may cope easier with quitting cigarette." One surprising result was that pack-year was higher in individuals with successful treatment compared to those with unsuccessful treatment. However, further studies are needed to clarify this relationship. Although the dependency scores were similar in both groups, as shown in previous studies, the individuals with high dependency and early relapse were found to be associated with treatment failure. ${ }^{[21]}$

While pharmacological treatments were found to decrease abstinence rates compared to the placebo group, a current randomized clinical study emphasized that pharmacotherapy has a relative efficiency and that the reason was not clear. ${ }^{[25]}$ Based on our findings, the use of varenicline and nicotine gum were not different between success and failure groups, whereas nicotine patch use was higher in the unsuccessful group. This suggests that the nicotine patch may affect the treatment result as the patch would be insufficient in rare severe urges due to its continuous release at basal level.

One of the limitations of the study was the lack of a standard measure or scale used to determine the calorie, fat-sugar intake, and the frequency and type of the hedonic food consumption while classifying the hedonic diet. It was not possible to determine the preferences of the study patients who accomplished the smoking cessation treatment during the treatment process with any scale due to the retrospective nature of the study. Another limitation was, again for the same reason, since it was not possible to put the individuals in a certain exercise program, the exercise preferences mentioned by the individuals by their words 
did not have a standard (exercise time, intensity, type, etc.). However, on the other hand, the retrospective nature of the study reflects the reality better in terms of the preferences of the individuals without any conditioning. Additionally, the absence of individuals taking bupropion in the study excludes any medication condition affecting the weight change and hedonic preferences.

\section{CONCLUSION}

In conclusion, the preference of hedonic foods in case of intense urge to smoke in patients who undergo smoking cessation treatment and implementing multiple strategies results in the success of the treatment, while exercise activity did not. We believe that this may provide a preliminary support to increase the treatment success by establishing smoking cessation programs in cooperation with dietitians to determine personal diet strategies (calorie, fat-limited, but tasty) and plan multiple strategies.

Ethics Committee Approval

This study was approved by the Hacettepe University Faculty of Medicine Ethics Committee (no: 2020/06-15).

Peer-review

Internally peer-reviewed.

Authorship Contributions

Concept: İ.ı.; Design: İ.ı., E.Ç.; Supervision: İ.I., C.D., Ü.S., E.K., A.Ö.; Materials: C.D., Ü.S., E.K., A.Ö.; Data: C.D., Ü.S., E.K., A.Ö.; Analysis: I..I., E.Ç.; Literature search: İ.I., E.Ç.; Writing: İ.ı.; Critical revision: E.Ç.

Conflict of Interest

None declared.

\section{REFERENCES}

1. Wu P, Wilson K, Dimoulas P, Mills EJ. Effectiveness of smoking cessation therapies: a systematic review and meta-analysis. BMC Public Health 2006;6:300-15.

2. Silagy C, Stead LF. Physician advice for smoking cessation. Cochrane Database Syst Rev 2001;2:CD000165

3. O'Connell KA, Hosein, VL, Schwartz JE, Leibowitz RQ. How does coping help people resist lapses during smoking cessation?. Health Psychology 2007;26:77-84.

4. Van Rensburg KJ, Taylor A, Hodgson T, Benattayallah A. Acute exercise modulates cigarette cravings and brain activation in response to smoking-related images: an fMRI study. Psychopharmacology 2009;203:589-98.

5. Taylor AH, Ussher MH, Faulkner G. The acute effects of exercise on cigarette cravings, withdrawal symptoms, affect and smoking behaviour: a systematic review. Addiction 2007;102:534-43.

6. Everson ES, Daley AJ, Ussher M. The effects of moderate and vigorous exercise on desire to smoke, withdrawal symptoms and mood in abstaining young adult smokers. Mental Health and Physical Activity 2008;1:26-31.

7. Zheng H, Lenard NR, Shin AC, Berthoud HR. Appetite control and energy balance regulation in the modern world: reward-driven brain overrides repletion signals. Int J Obes 2009;33:S8-13.

8. Liu Y, von Deneen KM, Kobeissy FH, Gold MS. Food addiction and obesity: evidence from bench to bedside. J Psychoactive Drugs 2010;42:133-45.

9. Lerman C, Berrettini W, Pinto A, Patterson F, Crystal-Mansour S, Wileyto EP, et al. Changes in food reward following smoking cessation: a pharmacogenetic investigation. Psychopharmacology 2004;174:571-7.

10. Karalezli A. Sigara Bırakma Poliklinikleri Nasıl Olmalı? Standartlar. [Article in Turkish]. Güncel Göğüs Hastalıkları Serisi 2016;4:73-7.

11. Fiore MC, Jaen CR, Bailey WC, Benowitz NL, Curry SJ, Henderson PN, et al. Treating tobacco use and dependence: 2008 update U.S. Public Health Service Clinical Practice Guideline executive summary. Respir Care 2008;53:1217-22.

12. Reichert J, Araújo AJ, Gonçalves CMC, Godoy I, Chatkin JM, Sales MP, et al. Smoking cessation guidelines - 2008. J Bras Pneumol 2008;34:845-80.

13. Heatherton TF, Kozlowski LT, Frecker RC, Fagerström KO. The Fagerström Test for Nicotine Dependence: a revision of the Fagerström Tolerance Questionnaire. Br J Addict 1991;86:1119-27.

14. IBM Corp. IBM SPSS Statistics for Windows, Version 23.0. Armonk, NY: IBM Corp; 2015.

15. Berridge KC. Food reward: brain substrates of wanting and liking. Neurosci Biobehav Rev 1996;20:1-25.

16. Epstein LH, Wright SM, Paluch RA, Leddy JJ, Hawk Jr LW, Jaroni JL, et al. Relation between food reinforcement and dopamine genotypes and its effect on food intake in smokers. Am J Clin Nutr 2004;80:82-8.

17. Gilbert RM, Pope MA. Early effects of quitting smoking. Psychopharmacology 1982;78:121-7.

18. Bush T, Lovejoy JC, Deprey M, Carpenter KM. The effect of tobacco cessation on weight gain, obesity, and diabetes risk. Obesity 2016;24:1834-41.

19. Billes SK, Greenway FL. Combination therapy with naltrexone and bupropion for obesity. Expert Opin Pharmacother 2011;12:1813-26

20. Ussher MH, Taylor AH, Faulkner GE. Exercise interventions for smoking cessation. Cochrane Database of Systematic Reviews 2014:1-72.

21. West R, Evins AE, Benowitz NL, Russ C, McRae T, Lawrence D, et al. Factors associated with the efficacy of smoking cessation treatments and predictors of smoking abstinence in EAGLES. Addiction 2018;113:1507-16.

22. Mckee SA, Smith PH, Kaufman M, Mazure CM, Weinberger AH. Sex differences in varenicline efficacy for smoking cessation: a meta-analysis. Nicotine Tob Res 2016;18:1002-11.

23. Yang JJ, Song M, Yoon HS, Lee HW, Lee Y, Lee SA, et al. What are the major determinants in the success of smoking cessation: results from the health examinees study. PloS one 2015;10:e143303.

24. Zimmerman RS, Warheit GJ, Ulbrich PM, Auth JB. The relationship between alcohol use and attempts and success at smoking cessation. Addict Behav 1990;15:197-207.

25. Baker TB, Piper ME, Stein JH, Smith SS, Bolt DM, Fraser DL, et al. Effects of nicotine patch vs varenicline vs combination nicotine replacement therapy on smoking cessation at 26 weeks: a randomized clinical trial. JAMA 2016;315:371-9. 


\section{Egzersiz Aktivite ve Gıda Tüketimi Davranışlarının Sigara Bıraktırma Programında Tedavi Başarısı Üzerine Etkisi}

Amaç: Sigara isteği ile başa çıkmada davranışsal stratejiler arzu seviyesini bastıırır ve sigarasız süreyi uzatır. Davranışsal stratejilerinden yeme içme tercihleri ve egzersiz aktivitelerinin başaçıkabilme ve sigara bırakma tedavisi başarısındaki rolü dikkat çekmektedir. Çalışmamızda sigara bırakma programı kapsamında tedavi alan hastalarda sigara içme isteği ile başa çıkabilmek için uygulanan davranışların hedonik gıda ve egzersiz özelliklerine göre değerlendirilmesi ve tedavi başarısına etkilerinin incelenmesi amaçlanmıştır.

Gereç ve Yöntem: Geriye dönük kohort çalışmamızda merkezimiz sigara bıraktırma programı kapsamında takip edilmiş II 9 hastanın demografileri, sigara bıraktırma tedavi özellikleri, bağımlılık düzeyleri, tedavi sonuçları, takip sürecinde sigara isteği halinde tercih edilen gıda ve aktiviteleri kaydedildi. Tedavi başarılı olan ve olmayan grupların verileri karşılaştıılarak incelendi.

Bulgular: Tedavi sürecinde ilk bir ay içerisinde sigarayı bırakanlar ve kilo artışı olanlar tedavi başarılı grupta daha fazlaydı (sırasıyla, $\mathrm{p}<0.00 \mathrm{I}$ ve $p<0.00 \mathrm{I}$ ). Tedavi başarısız grupta yüksek bağımlılık ve tedavi sürecinde relapse daha fazla saptandı (sırasıyla, $p=0.04, p=0.00 \mathrm{I}$ ). Farmakolojik tedavilerden vareniklin ve nikotin sakızı kullanımı gruplara göre farklıık göstermemekteydi. Ancak nikotin bant kullanımı tedavi başarısız grupta daha fazla idi $(p=0.046)$. Sigara içme isteği halinde uygulanan davranışsal stratejiler arasında hedonik diyet tercih edenlerin tedavi başarılı grupta fazla olduğu görülürken $(p=0.04)$, non-hedonik diyet, egzersiz aktivite ve egzersiz yapmama aktivite tercih edenler her iki grupta da benzerdi.

Sonuç: Sigara bırakma tedavisi alan bireylerin sigara içme isteği halinde hedonik gıda tercih etmesi ve çoklu strateji uygulanması tedavi başarıı ile ilişkilidir. Egzersiz aktivite tedavi başarısı ile ilişkisizdi. Çalışma sonuçları, bireye uygun diyet stratejileri belirleme ve çoklu strateji planlaması ile sigara bırakmada tedavi başarı şansını arttıracağına dair ön kanıt sağlamaktadır.

Anahtar Sözcükler: Davranışsal strateji; egzersiz aktivite; hedonik diyet; sigara bırakma. 